\title{
POSITIVE ECOLOGICAL PRACTICES FORMATION AS CONDITION OF ECOLOGICAL CRISIS OVERCOMING
}

\author{
O. Kolosova \\ Krasnodar University of the Ministry of Internal Affairs of the Russian Federation \\ Krasnodar, Russian Federation \\ kolosova.07@mail.ru \\ V. Goncharov \\ North Caucasus federal university Stavropol, Russian Federation \\ vgn1968@rambler.ru
}

\begin{abstract}
Development of social ecological practices, their wide spreading through the system of scientific knowledge, education and upbringing, formation of ecological structure can contribute to overcoming of ecological crises, satisfaction of society primary demands and provision of worthy life level for every person. The content and constructive orientation of social ecological practices of a person in a greater degree are conditioned by balance between ecological problems, which touch upon the quality of life and make somebody to undertake active steps for ecological threat removal, ecological hazard overcoming, by original mountings for reformation (by intentions) of environment, by social qualities, determining the optimal choice of social changes model, by conventions as mutually agreed actions of social subjects in the general sociocultural and natural space, and, eventually, by social technologies as the practice instruments. The phenomenon of socially ecological practices has the close interconnection with structure transformations in all spheres of the society activity. The indice of social health represent the indicator of given transformations. The social health characterizes vitality of the society. The social health index represents correlation of healthy and unhealthy life mode of population. Institutionalization of ecological practices relating to an integral health index is in the third levels of social reality: social structures, person and culture. Social ecological practices represent a double phenomenon, where positive and negative processes closely interlace. The last one manifests in the low level of ecological structure, expressing in all aspects of a person's life (the low level of ecological enlightenment, education, upbringing and behavior). Under the condition of involvement in all social institutes the positive social ecological practices represent the meaning of innovative ecological modernization of all Russian society regions. They are not only appealed to transform socionatural reality of the modern society, but contribute to the choice of ecologically-efficient models of daily behavior, socionatural activity, reflecting the necessity of spiritually-moral attitude recreation towards nature. Ecological ideology, as axiological component of ecological culture, purposefully influences to ecological humanism formation, understanding of nature as the highest panhuman value. Ecological humanism, as the modern form of humanism includes the following principles: harmony of a person with nature; equivalence of everything alive; non-violence; selfcontainment instead of consumerism; a loving and creative personality formation; necessity of moral selfimprovement; preservation of diversity of nature, person and culture. The fast development of cottage construction, organization of suburban cooperatives, ecological tourism, amenity planting of inhabited localities, creation of protected areas in the cities, ecosettlements, environmental ethics that speaks for restoration of preservation demand and augmentation of natural resources and coevolutionary development of society and nature.
\end{abstract}

Key words: ecology, ecological sphere, ecological problem, ecological practices, social development.

[Колосова О.Ю., Гончаров В.Н. Формирование позитивных экологических практик как условие преодоления экологического кризиса]

Развитие позитивных социальных экологических практик, их широкое распространение через систему научного знания, образования и воспитания, формирование экологической культуры может способствовать преодолению экологического кризиса, удовлетворению первостепенных потребностей общества и обеспечению достойного уровня жизни каждого человека. Содержание и конструк- 
тивная ориентированность социальных экологических практик человека в большей степени обусловлены балансом между экологическими проблемами, которые затрагивают качество жизни и заставляют предпринимать активные шаги для снятия экологической угрозы, преодоления экологической опасности, исходными установками на преобразование (интенциями) окружающей среды, социальными качествами, определяющими оптимальный выбор модели общественных изменений, конвенциями как взаимосогласованными действиями социальных субъектов в общем для них социокультурном и природном пространстве, и, наконец, социальными технологиями как инструментами практик. Феномен социальных экологических практик имеет тесную взаимосвязь со структурными трансформациями во всех сферах жизнедеятельности общества. Показатели общественного здоровья представляют собой индикатор данных трансформаций. Общественное здоровье характеризует жизнеспособность общества. Индекс общественного здоровья представляет собой соотношение здорового и нездорового образа жизни населения. Институционализация экологических практик применительно к интегральному показателю здоровья находится в трех уровнях социальной реальности: общественных структур, личности и культуры. Социальные экологические практики представляют собой двойственное явление, в котором тесно переплетаются позитивные и негативные процессы. Последние проявляются в невысоком уровне экологической культуры, выражающемся во всех аспектах жизнедеятельности человека (низкий уровень экологического просвещения, образования, воспитания и поведения). При условии включенности во все социальные институты позитивные социальные экологические практики представляют собой средство инновационной экологической модернизации всех регионов российского общества. Они не только призваны трансформировать социоприродную реальность современного общества, но и способствуют выбору экологически целесообразных моделей повседневного поведения, социоприродной деятельности, отражающих необходимость воссоздания духовно-нравственного отношения к природе. Экологическая идеология, как аксиологический компонент экологической культуры, целенаправленно влияет на формирование экологического гуманизма, понимание природы как высшей общечеловеческой ценности. Экологический гуманизм как современная форма гуманизма включает в себя следующие принципы: гармония человека с природой; равноценность всего живого; ненасилие; самоограничение вместо потребительства; становление любовно-творческой личности; необходимость нравственного самосовершенствования; сохранение разнообразия природы, человека и культуры. Проявлением социальных экологических практик на современном этапе развития общества является быстрое развитие коттеджного строительства, организация дачных кооперативов, экологический туризм, озеленение населенных пунктов, создание заповедно-парковых зон в городах, экопоселений, экологическая этика, что свидетельствует о восстановлении потребности сохранения и приумножения природных богатств и коэволюционного развития общества и природы.

Ключевые слова: экология, экологическая сфера, экологические проблемы, экологические практики, общественное развитие.

Olga Yu. Kolosova - Ph.D. of Philosophy, professor. Krasnodar University of the Ministry of Internal Affairs of the Russian Federation. Krasnodar, Russian Federation.

Vadim N. Goncharov - Ph.D. of Philosophy, professor. Institute of the Humanities of the North Caucasus federal university. Stavropol, Russian Federation.

Колосова Ольга Юрьевна - доктор философрких наук, профрессор. Краснодарский университет Министерства внутренних дел Российской Федерации. Краснодар, Россия.

Гончаров Вадим Николаевич - доктор философрских наук, профрессор. Гуманитарный институт Северо-Кавказского федерального университета. г. Ставрополь, Россия.

Processes of degradation of the surrounding environment are caused by the negative social practices based on the consumer society values, characterized by the low level of ecological culture, lack of exhaustive ecological information. All this causes the crisis phenomena, decline in quality of life and deterioration in human health, mismatch of economic, social, cultural and ecological interests of various social groups. These signs can be found in political, legal, economic, social, information, educational and other spheres of society. Nowadays there is a need of changes in the ecological sphere of society, it is caused by need of a person and society of adaptation to the future and need of creation 
within the space of culture, educational space positive social ecological practices, their use in everyday life of each person and society in general.

It is known that social practices develop in the course of joint activity of people whose goal-setting is change of quality of their social being in compliance with their installations, social capital that is social communications which can represent a benefit acquisition resource. Speaking about such practices, first of all, it is necessary to focus attention on their consequences and results. First, social practices lead to change of quality of life. Quality of the social environment (life) of the person acts as an integrative indicator of practical activities. It assumes not only subjective satisfaction with life, but also improvement of the general life comfort, and change of its social standards. Secondly, active social practices promote increase in the social capital of the subject which is created for achievement of his own advantages and assumes the social contract, a set of social norms (standards) and the organization of social contacts (exchanges) organized at the basic level of trust [3, c. 29-34]. Thirdly, social practices are made by the subjects allocated not only with consciousness and will, but also with social intensions - installations on high-quality changes of the social environment which are embodied in concrete models and forms of their daily behavior $[6,8,10]$. The basic concepts which define meaning of social practices of the person are: "social problems", "social intensions", "social properties", "social conventions".

In this context the concept "environmental problems" designates the difficult complexes of questions reflecting those aspects of contradictions of socio-natural life which pose a direct threat for their way of life in consciousness of subjects and give the grounds for concern (sense of danger, concern, discomfort) and as a result response - activity of these subjects for the purpose of change of an adverse ecological situation to the best. In other words, environmental problems fix process and result of understanding by the person of difficult socio-natural contradictions requiring the immediate solution. The person as the subject of social practice deals with the problems which solution influences in general his quality of life and depends first of all on the level of his competence (professional, communicative) and his own resources. Identification and justification of the existing environmental problems in practical action is implemented by means of the following procedures:

1) identifications, that is recognition of real socio-natural contradictions creating problems of insufficient quality of social life, and their separation from imaginary or nonexistent contradictions;

2) rationalization of problems, that is procedure of definition and assessment of degree of resolvability of these contradictions;

3) qualifications - estimates of level of competence of the subject and existence of resources (first of all social capital), problems necessary for the decision.

Social intensions as initial orientations of subjects of practical activities express their generalized readiness to change the socio-natural environment, using the social capital which is available for him and updated his personal potential. Social intensions include immanently admissible level of changes of socio-natural reality. We deal with the special procedure, namely - rationalization of resources that is with identification and an assessment of resources which can be involved by the subject in his practical ecological activities. However, only readiness for change of the socio-natural environment is insufficient. It is still necessary to estimate possibilities of use both actual resources, available to the subject, and the resources provided to him by society and other subjects. At the same time readiness to the change quality of the socio-natural environment assumes also refusal of the subject from some life conditions, habitual for him. Therefore, he, to make "external" 
social changes, has to be ready for "internal" changes, including self-restriction for the solution of socially important environmental problems.

Starting transformation of the life, the person constantly has a choice: to leave or lose the former way of life for realization of this or that model of social change. Conventionality is an important property of social ecological practices and their major prerequisite. No one can transform the socio-natural environment, without entering partner agreements with other subjects and forcing them to consider his own interests. Social and ecological practices form a general space of interaction for all people in which decisions are implemented further in the course of joint activity.

An important role is played by social technologies - ways of the rational organization and reconstruction of any activity of the person which are carried out for the purpose of its optimization (increase in efficiency) and by means of development of the new algorithm allowing ordering in a different way its functions, structure and process [2, p. 37-40; 9]. In this context, the best ecological practice is the most effective and successful, from the ecological, economic and social point of view, use of the best available technology or other technology in economic activity, taking into account national, regional and local peculiarities.

The structure of social and ecological practices includes values of ecological culture, ecological activity, experience, skills, ecological knowledge which being "the integral attribute of elaborate society, and also socio-natural interaction, it has to reflect all completeness of the world and informative methods, unite elements and blocks of knowledge in uniform integrity" [3]. The ecological culture means not only new humanity, but humanity in true and highest value of this word as environment-oriented can't be directed against the person as well as against other life forms.

All this requires approval and further development of already existing system of interaction social ecological practices, in particular, such as environmental policy, ecological management, ecological or "green" banking, ecological tourism, ecovillages, children's ecological camps, etc. Rybakova M. V. defines social ecological practices as a system of individual and collective actions caused by condition of culture and the level of development of society, change of nature of interaction of the person and society with the environment, for the purpose of restoration of the destroyed ecosystems and preserving of the existing [5]. Worldview, cognitive and activity aspects are allocated in structure of social and ecological practices. Social ecological practices can be both individual, and group, collective.

Revival of natural ecosystems becomes a transnational idea designed not only to compensate the loss caused to the surrounding environment by resource-intensive activity of the person but also to lead the globe to the valid prosperity. Social ecological practices in the modern society are shown in quick development of cottage building co-operatives, cottage construction, ecological tourism, gardening, creation of reserved and park zones in the cities, ecovillages, and more responsible attitude to fauna that demonstrates revival of requirement of preservation and enhancement of natural wealth and communication with the nature.

Ecological modernization of regions of Russia provides social ecological practices on creation of reserves, wildlife areas, use in the modern city planning of the ecological principles, doing possible formation of a mosaic landscape, development of the cities in the type "garden city", "city nature", "green city". Positive social ecological practices can act as the innovative direction of ecological modernization of all regions of the Russian society on condition of their inclusiveness in all social institutes. They can change not only socionatural reality of the modern society, and also a model of daily behavior, socio-natural ac- 
tivity on eco-corresponding, reflecting spiritual and ecological determination of further civilization development. The spiritual sphere of activity of society, passing to a new stage of development, includes except the sphere of ideology and morals, the sphere of ethics. The main task of ecological ethics consists in designing of the system of standard installations defining the relation, behavior, actions of the person directed to his natural environment. The multilevelness of the evolving reality causes an ethics multilevelness, the individual divides general responsibility for society, for culture, for nature, for his own creations, etc. There is a problem to connect individual ethics to ethics of complete system, to the general ethics of evolutionary process, coordinating thereby activity of the person with evolutionary dynamics.

It should be noted that in the modern Russian society there are negative social ecological practices demanding change on positive at the individual and collective levels as a condition of formation, reproduction and transformation of the society nature system. Overcoming negative tendencies in the sphere of environmental management requires change of a vector of social and ecological practices through ecological modernization of all Russian society, formation of ecological culture and coevolution consciousness, effective environmental policy, system of ecological banking and business, transition from resource-intensive to resource-saving economic system [4, 6, 7].

The phenomenon of social and ecological practices is closely connected with structural changes in all spheres of activity of society and indicator of these changes is indicators of public health. Public health characterizes viability of society. An index of public health is ratio of healthy and unhealthy way of life of the population. Content of process of ecological practices can't be realized out of health of the population as ecological practices are mediated by the state of health of the population. The self-preservation behavior is understood as preservation of health as one of the main values in the system of social and valuable orientations [5]. It is based on knowledge of the surrounding nature making huge impact on health of the person, on understanding of unity of the physiological and spiritual processes happening in the person.

As important component of such behavior is a biological instinct of self-preservation of the person which is transformed under the influence of welfare conditions from a biological instinct to the conscious line of conduct including self-knowledge, analysis of his own health state, and the most important - willpower and desire to realize the behavior conforming to requirements of the healthy lifestyle, sanitary and hygienic and medical instructions acts.

Health in the escalating degree is comprehended as a significant phenomenon of social life, as a structure-forming factor of the sociality. In the science there are attempts to investigate health in its objective generality, in the space of social evolution, in the relation to community as to the subject of historical action at a certain stage of formation. The institutionalization of ecological practices concerning an integrated indicator of health lies in the plane of three levels of social reality: public structures, personality and culture. For an assessment of health of a certain group of people or the population in general it is accepted to use the following groups of indicators: indicators of medico-demographic processes; incidence indicators; disability indicators; indicators of physical health. Rybakova M.V. allocates such institutionalized social practices of maintenance of health as system of the state health care (medical examination, prophylaxis of occupational diseases, sanatorium treatment) of society and awareness of health as supreme value of improvement of quality of life, self-preservation behavior, formation of the healthy lifestyle, social ecological practices in the field of children health formation. The existing contradiction between system of the state health care, state policy in this area and the person, culture and 
social structure is push for change social ecological practices. Complex use of various methodological principles, allows to consider really influence of various factors on health, and also to understand their influence on process of improvement of quality of life, selfpreservation behavior:

1) sociocultural changes (health nowadays is at the lowest level of hierarchy of values) resulting in risk of diseases;

2) socio-economic factors;

3) social and ecological factors including various risk factors (biospheric, social, ecological, technogenic);

4) structure-forming factors (social and political);

5) sanitary and hygienic.

It is possible to claim that the value of health and safety of the environment for the present are not so important in hierarchy of values of the modern personality, but individual ecological practices become more active, mobile and selective, and the selfpreservation behavior can become one of the ways of the society positive ecological practices formation.

\section{Лumepamypa}

1. Ворожко Ю.Н., Несмеянов Е.Е., Руденко А.М. Философия самореализации личности в современной культуре. Новочеркасск, 2015.

2. Камалова О.Н., Джиоева Д.А. Перспективы развития сенсорных технологий и проблема расширения чувственных возможностей человека // СевероВосточный научный журнал. 2011. № 1.

3. Колосова О.Ю. Системно-методологические основания экологического знания // Гуманитарные и социально-экономические науки. 2008. № 5.

4. Матяш Т.П., Матяш Д.В., Несмеянов Е.Е. «Науки о природе» и «науки о духе»: судьба старой дилеммы // Гуманитарные и социально-экономические науки. 2015. № 1 (80).

5. Рыбакова М.В. Экологические практики в социокультурном контексте: монография. М., 2008.

6. Kolosova O.Y., Goncharov V. N. Economic and ecological safety of the region: strategy choice // Научный альманах стран Причерноморья. 2015. № 3. http://science-almanac.ru

7. Kolosova O.Y., Goncharov V.N. Spiritual life of society: regional aspect // Научный альманах стран Причерноморья. 2015. № 4. http://science-almanac.ru

8. Nesmeyanov E.E., Rudenko A.M., Kotlyarova V.V. Sociocultural analysis of cyberterrorism in social nets within the problems of information safety of Russian society // Научный альманах стран Причерноморья. 2015. № 4 (4).

9. Meskhi B.Ch., Astvatsaturov A.E. Human factor in solving engineering problems of safety Science almanac of Black Sea region countries". 2015. № 1. http://sciencealmanac.ru

10. Sklyarova E.K. Comparative aspects of scientific research of the urbanization problem // Научный альманах стран Причерноморья. 2016. № 2. http://sciencealmanac.ru 


\section{References}

1. Vorozhko Yu.N., Nesmeyanov E.E., Rudenko A.M. Philosophy of person's selfrealization in the modern culture. Novocherkassk, 2015.

2. Kamalova O.N., Dzhioeva D.A. Prospects for the development of sensory technologies and the problem of human sensory capabilities expanding // North-Eastern scientific journal. 2011. No 1.

3. Kolosova O.Yu. System-methodological foundations of environmental knowledge // Humanities and socio-economic sciences. 2008. No 5.

4. Matyash T.P., Matyash D.V., Nesmeyanov E.E "Sciences about nature" and "sciences about spirit": the destiny of the old dilemma // Humanities and socioeconomic sciences. 2015. No 1 (80).

5. Rybakova M.V. Ecological practices in sociocultural context: monography. M., 2008.

6. Kolosova O.Y., Goncharov V. N. Economic and ecological safety of the region: strategy choice // Science almanac of Black sea region countries. 2015. No 3. http://science-almanac.ru

7. Kolosova O.Y., Goncharov V.N. Spiritual life of society: regional aspect // Science almanac of Black sea region countries. 2015. No 4. http://science-almanac.ru

8. Nesmeyanov E.E., Rudenko A.M., Kotlyarova V.V. Sociocultural analysis of cyberterrorism in social nets within the problems of information safety of Russian society // Science almanac of Black sea region countries. 2015. No 4 (4).

9. Meskhi B.Ch., Astvatsaturov A.E. Human factor in solving engineering problems of safety Science almanac of Black Sea region countries. 2015. No 1. http://sciencealmanac.ru

10. Sklyarova E.K. Comparative aspects of scientific research of the urbanization problem // Science almanac of Black sea region countries. 2016. No 2. http://sciencealmanac.ru 